\title{
Situation Vacant
}

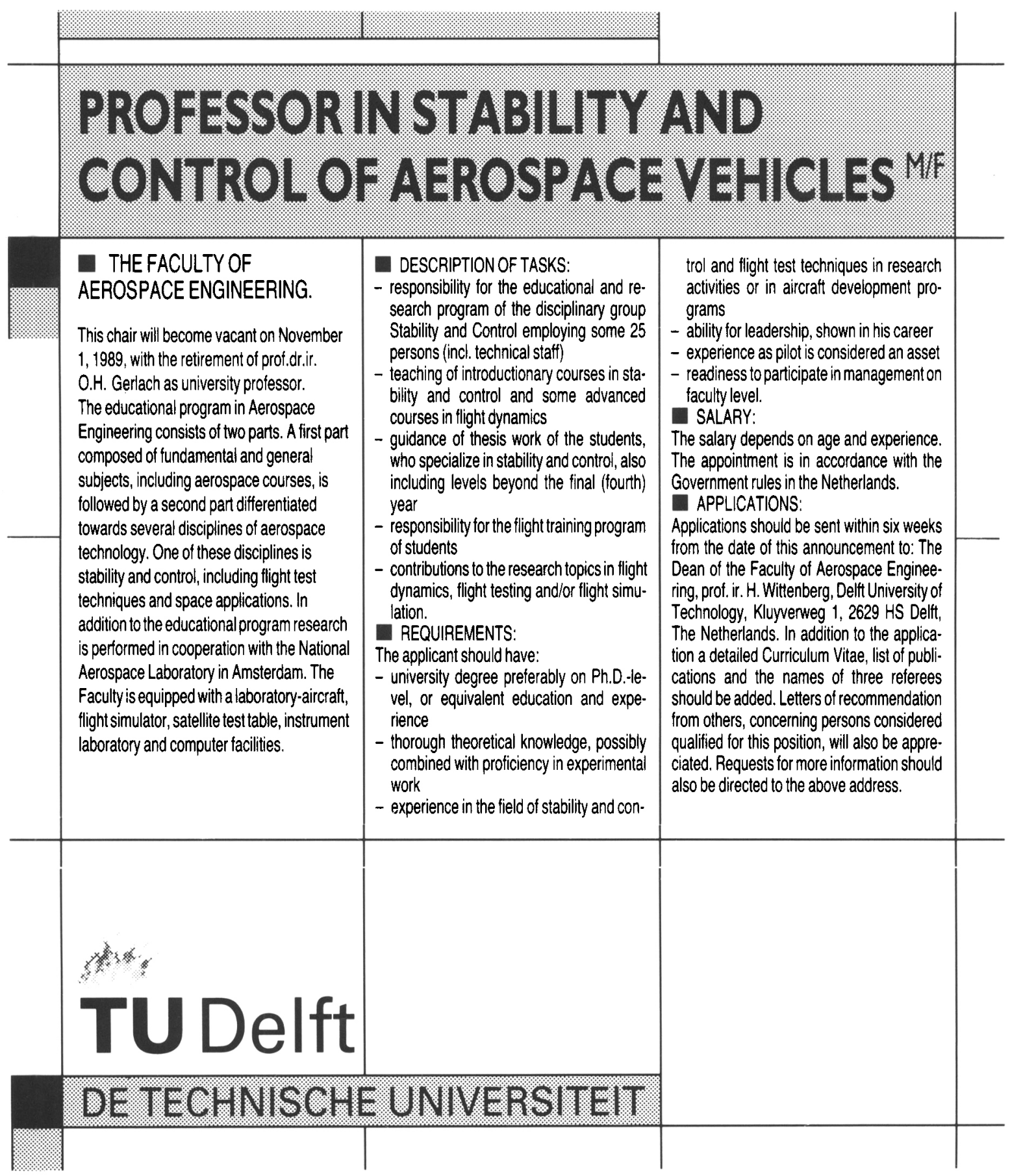


https://doi.org/10.1017/S0001924000016328 Published online by Cambridge University Press 